\title{
AKTIVITAS ANTIBAKTERI DAN PERUBAHAN MORFOLOGI DARI PROPIONIBACTERIUM ACNES SETELAH PEMBERIAN EKSTRAK CURCUMA XANTHORRHIZA
}

\author{
Halimatus Zahrah $^{1}$, Arifa Mustika ${ }^{2}$, Kartuti Debora ${ }^{2}$ \\ ${ }^{1,3}$ Program Pascasarjana Fakultas Kedokteran, Universitas Airlangga; Jl. Airlangga No. 4-6 \\ Kampus B, Surabaya (60286) Telp: 031-5041566, 5041536 \\ ${ }^{2}$ Program Pascasarjana Fakultas Kedokteran, Universitas Airlangga, Surabaya \\ e-mail: zbcindonesia@gmail.com, ${ }^{2}$ arifa-m@fk.unair.ac.id, ${ }^{2}$ kartutidebora@gmail.com
}

\begin{abstract}
Abstrak
Penatalaksanaan utama pada masalah akne vulgaris adalah penggunaaan antibotik baik topikal maupun oral. Akan tetapi penggunaan antibiotik dinilai telah menimbulkan dugaan resistensi terhadap P. acnes sebagai agent penyebab akne sehingga mendorong berbagai pihak untuk mengembangkan preparat antiinflamasi yang dapat diberikan topical ataupun sistemik. Curcuma xanthorrhiza Roxb. memiliki senyawa utama xanthorrizol yang dinilai potensial untuk dikembangan sebagai antibakteri. Tujuan penelitian ini adalah untuk mengetahui kadar hambat minimum dan kadar bunuh minimum serta perubahan struktur dinding sel dari Curcuma xanthorrhiza Roxb. terhadap pertumbuhan Propionibacterium acnes. Desain penelitian yang di gunakan adalah eksperimen dengan sampel P. acnes berupa isolate stock culture (ATCC $^{\circledR}$ $11827^{\mathrm{TM}}$ ) yang selanjutnya ditumbuhkan pada media MHA. Jumlah replikasi yang digunakan sebanyak 4 ulangan. Konsentrasi ekstrak Curcuma xanthorrhiza Roxb. masing-masing 6,25 $\mu \mathrm{g} / \mathrm{ml}, 12,5 \mu \mathrm{g} / \mathrm{ml}, 25 \mu \mathrm{g} / \mathrm{ml}, 50 \mu \mathrm{g} / \mathrm{ml}$ dan $100 \mu \mathrm{g} / \mathrm{ml}$. Pengukuran aktivitas antibakteri didasrkan pada KHM, KBM dan pengamatan struktur dinding sel bakteri melalui metode Microscop Electron Screening (MES). Pemberian ekstrak Curcuma xanthorrhiza Roxb. memiliki efek antibakteri terhadap bakteri P. acnes secara in vitro. Konsentrasi ekstrak $25 \mu \mathrm{g} / \mathrm{ml}$ merupakan kadar minimum yang mampu menghambat pertumbuhan P.acnes melalui dilusi cair, sedangkan konsentrasi minimal yang mampu membunuh P.acnes adalah $50 \mu \mathrm{g} / \mathrm{ml}$. Bakteri P. acnes yang dipapar dengan ekstrak etanol Curcuma xanthorrhiza Roxb. mengalami perubahan morfologi berupa timbulnya dinding sel kasar kasar akibat penyusutan serta adanya dinding sel yang hancur sehingga sitoplasma keluar dan tampak seperti meleleh. Respon daya hambat pertumbuhan bakteri yang dihasilkan Curcuma xanthorrhiza Roxb. dipengaruhi oleh senyawa aktif yang terkandung didalamnya seperti minyak atsiri, alkaloid, flavonoid, tanin, kurkuminoid dan terpenoid. Kandungan xanthorrizol yang dimiliki mampu menghambat pertumbuhan P.acnes mampu merusak aktivitas enzim sel, selain itu kandungan Curcuminoid turut berperan dalam menghambat pertumbuhan bakteri dengan cara mendenaturasi dan merusak membran sel sehingga proses metabolisme sel terganggu
\end{abstract}

Kata Kunci: Antibakteri, Akne vulgaris, Curcuma xanthorriza Roxb., MES

\section{PENDAHULUAN}

Akne vulgaris (jerawat) di kawasan Asia Tenggara, terdapat 40-80\%, kasus sedangkan di
Indonesia menurut catatan studi dermatologi kosmetika Indonesia menunjukkan yaitu $60 \%$ penderita akne vulgaris pada tahun 2014, $80 \%$ pada tahun 2015 dan 90\% pada tahun 2016. 
Prevelansi tertinggi yaitu pada umur 14-17 tahun, dimana pada wanita berkisar $83-85 \%$ dan pada pria yaitu pada umur 16-19 tahun berkisar 95100\% (Afriyanti, 2015). Propionibacterium acnes dan staphylococcus epidermis adalah mikroba pembentuk nanah yang bertanggung jawab untuk pengembangan berbagai bentuk, akne vulgaris. Meskipun akne vulgaris tidak mengancam kehidupan, namun dapat menyebabkan masalah serius dalam kondisi sosial dan psikologis penderita. Hasil penelitian Vilar (2015) yang menunjukkan bahwa dari 317 responden yang memiliki masalah jerawat, $48,6 \%$ diantaranya merasa stres, $19,4 \%$ takut untuk berfoto, $22 \%$ takut bertemu seseorang untuk pertama kali dan 8,5\% takut untuk bertemu dengan teman.

Penatalaksanaan akne vulgaris dibagi berdasarkan derajat keparahannya, pada akne derajat ringan terapi yang diberikan hanya pengobatan topikal diantaranya asam retinoal atau benzoil peroksida. Pengobatan akne derajat sedang dan berat dapat ditambahkan terapi oral dengan menggunakan Doksisiklin ataupun antibiotik lain, namun pada ibu hamil dan menyusui direkomendasikan untuk memberikan antibiotik eritromisin (Widaty dkk, 2017). Tetrasiklin banyak digunakan untuk akne inflamasi, akan tetapi tetrasiklin mulai ditinggalkan karena angka resistensi terhdap $P$. acnes yang cukup tinggi. Turunan tetrasiklin yaitu doksisiklin dan minosiklin menggantikan tetrasiklin sebagai terapi antibiotik oral lini pertama, namun eritromisin juga dibatasi penggunaannya hanya pada ibu hamil karena mudah terjadi resistensi $P$. acnes (Yenni, 2011). Penggunaan antibiotika secara terus-menerus dapat menyebabkan resisten.

Prevalensi $P$. acnes resisten antibiotik bervariasi di berbagai negara. Prevalensi tinggi terjadi di berbagai negara eropa dengan resistensi eritromisin/klindamisin berkisar antara 45\%-91\% dan resistensi tetrasiklin dari $5 \%$ menjadi $26,4 \%$. Prevalensi $P$. acnes resisten antibiotik di wilayah asia terdapat perbedaan yang besar misalnya di Jepang, tingkat resisten eritromisin atau klindamicin hanya $4 \%$ dan tetrasiklin atau doksisiklin hanya 2\%. Sedangkan di Korea, penelitian terbaru hanya menemukan satu dari 33 strain $(3,2 \%)$ yang diisolasi resisten terhadap klindamisin hal tersebut dikarenakan $P$. acnes resisten antibiotik belum berkembang cukup baik di Korea, sedangkan hasil penelitian di Indonesia resistensi $P$. acnes terhadap antibiotik tetrasiklin sebesar $12,9 \%$, eritromisin $45,2 \%$ dan klindamisin $61,3 \%$ sedangkan pada doksisiklin dan minosiklin tidak didapatkan resistensi (Madelina, 2019).

Penggunaan antibiotik topikal hanya memicu resistensi terbatas pada area yang dirawat tetapi pada penggunaan antibiotik oral resistensi dapat berkembang ke seluruh area tubuh. Berdasarkan tinjauan sistematis terhadap 50 uji klinis penggunaan antibiotik topikal, terdapat penurunan efektifitas eritromisin topikal pada jerawat baik pada lesi inflamasi maupun non-inflamasi yang diduga terkait dengan perkembangan resistensi antibiotik dari $P$. acnes (Clatici, 2015). Hasil penelitian lain menunjukkan munculnya masalah penggunaan eritromisin topikal dalam jangka panjang memicu prevalensi penderita mengalami eritromisin yang resisten terhadap Staphylococcus dan Streptococcus (Leyden, 2009). Beberapa dari efek samping resistensi antibiotik berdasarkan hasil penelitian terdahulu diantaranya adalah infeksi saluran pernapasan dimana resiko terjadinya infeksi saluran pernafasan akut (ISPA) pada individu dengan jerawat yang menerima antibiotik 2,15 kali lebih besar dari pada individu yang tidak menerima antibiotik. Hasil penelitian kohort lain didapatkan resiko terjadinya faringitis pada pasien akne dengan terapi antibiotik sebesar 4,34 selain itu berbagai hasil studi lain juga menunjukkan adanya resiko timbulnya gangguan pembuluh vaskular, radang usus dan kanker pada pasien akne dengan yang mendapatkan terapi antibiotik (Garret, 2012).

Timbulnya dugaan resistensi penggunaan antibiotik sebagai terapi jerawat mendorong berbagai pihak untuk mengembangkan preparat antiinflamasi yang dapat diberikan topical ataupun sistemik, misalnya topical nikotinamide untuk mengobati akne meradang ringan dan sedang, sementara benzoyl peroxide dalam obat oles anti akne vulgaris dianggap sebagai desinfektan oles yang dijual bebas dan paling efektif dalam terapi bekas noda bekas akne vulgaris. Oleh karena itu diperlukan alternatif bahan obat sebagai antibiotik terhadap $P$. acnes pada penatalaksanaan masalah Akne vulgaris utamanya yang berasal dari bahanbahan alam untuk meminimalisir efek samping (Niyomkam, 2010).

Kandungan potensial sebagai antibakteri yang dimiliki oleh Curcuma xanthorrhiza Roxb. adalah flavonoid. Flavonoid merupakan turunan 
senyawa fenol yang dapat menyebabkan terganggunya integritas dinding dan membran sel bakteri yang dapat dilihat dari perubahan ukuran dan morfologi sel bakteri (Jail, 2008). Kandungan bahan aktif pada Curcuma xanthorrhiza Roxb. yang berpotensi sebagai antimikroba membuat banyak pihak yang tertarik untuk memanfaatkannya sebagai terapi topikal jerawat. Saat ini telah beredar secara bebas berbagai jenis krim Temulawak yang masih dipertanyakan hasil uji klinis serta legalitasnya dari badan pengawas obat dan makanan BPOM sehingga tingkat dosis maksimal serta Kadar Hambat Minimum (KHM) serta Kadar Bunuh Minimum (KBM) produk belum dapat diandalkan.

Berdasarakan latar belakang tersebut ditetapkan tujuan penelitian yaitu: mengetahui kadar hambat minimum dan kadar bunuh minimum serta perubahan struktur dinding sel dari Curcuma xanthorrhiza Roxb. terhadap pertumbuhan Propionibacterium acnes

\section{TINJAUAN PUSTAKA}

\subsection{Propionibacterium acnes}

Akne vulgaris adalah reaksi dari penyumbatan pori-pori kulit disertai peradangan yang bermuara pada saluran kelenjar minyak kulit. Sekresi minyak kulit menjadi tersumbat, membesar dan akhirnya mengering menjadi akne vulgaris (Muliyawan dan Suriana, 2013). Akne vulgaris adalah penyakit peradangan kelenjar sebasea yang sering dijumpai dan berkaitan dengan folikel rambut (disebut unit polisebasea). Terdapat dua jenis akne yaitu meradang dan tidak meradang. Kedua jenis akne tersebut ditandai oleh pembentukan sebum yang berlebihan. Sebum yang berlebihan tersebut tertimbun di folikel sehingga folikel membengkak.

P.acnes merupakan bakteri gram positif yang secara morfologi dan susunannya termasuk dalam kelompok bakteri corynebacteria, tetapi tidak bersifat toksigenik. Bakteri ini termasuk flora normal pada kulit, P.acnes merupakan bakteri yang memiliki peranan yang penting dalam patogenesis akne vulgaris dengan menghasilkan lipase yang memecah asam lemak bebas dari lipid kulit. Asam lemak ini dapat mengakibatkan inflamasi jaringan ketika berhubungan dengan sistem imun dan mendukung terjadinya akne vulgaris. P.acnes termasuk bakteri yang tumbuh lambat. Bakteri ini tipikal bakteri anaerob gram positif yang toleran terhadap udara (Putri, 2010).

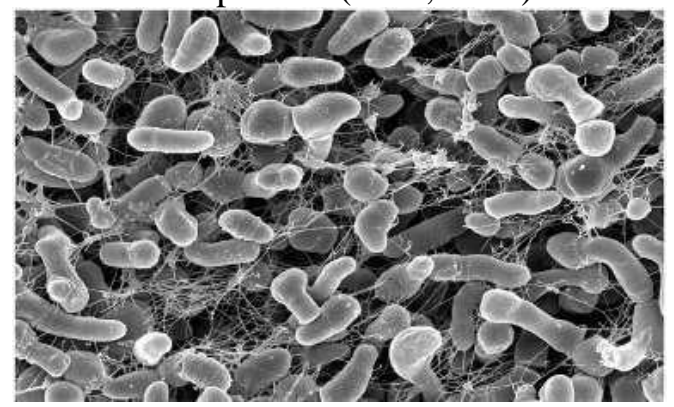

Gambar 1 Hasil Pengamatan Mikroskop Skrening Elektron (MES) Propionibacterium acnes (Science Direct, 2016)

\subsection{Curcuma xanthorhizza Roxb.}

Temulawak (Curcuma xanthorrhiza Roxb.) merupakan kelompok jahe-jahean yang tumbuh setinggi 1,5 m. Rimpang temulawak merupakan bagian yang paling banyak digunakan dan merupakan unsur integral dari masakan dan obat-obatan di Asian. Konsumsi temulawak secara teratur terbukti memberikan perbaikan signifikan dari kekakuan sendi di pagi hari, meningkatkan kecepatan berjalan dan mengurangi pembengkakan sendi (Watson, 2019). Temulawak dapat tumbuh baik di dataran rendeh hingga ketinggian 750 meter di atas permukaan laut. Temulawak dikembangbiakan dari rimpang, rimpang yang dipilih sebagai bibit adalah yang sudah dalam keadaan kering (Adiwijaya, 2010). Secara tradisional, temulawak banyak digunakan untuk mengobati batu ginjal, demam, kadar kolesterol tinggi, nyeri sendi, dan hepatitis. Banyak penelitian yang telah dilakukan pada komponen aktif rimpang temulawak dalam potensinya sebagai antioksidan, antilipidemia, antibakteri dan antijamur (Batubara, 2015).

\section{METODE PENELITIAN}

\section{Rancangan Penelitian}

Jenis penelitian yang digunakan di dalam penelitian ini yaitu metode eksperimen (experimental), dengan rancangan post test 
Jurnal Biosains Pascasarjana Vol. 20 (2018) pp

(C) (2018) Sekolah Pascasarjana Universitas Airlangga, Indonesia

only control group design.

\section{Sampel dan Besar Sampel}

Sampel pada penelitian ini adalah Propionibacterium acnes berupa isolate stock culture American Type Culture Collection (ATCC) dengan nama Propionibacterium acnes $\left(\mathrm{ATCC}^{\circledR} 11827^{\mathrm{TM}}\right.$ ) yang diperoleh dari laboratorium di Medan untuk selanjutnya ditumbuhkan dalam media Mueller Hinton Agar (MHA) dan diinkubasi pada suhu $35^{\circ} \mathrm{C}$ selama 24 jam dengan kondisi kadar karbon dioksida sebesar 5\%-10\% (Forbes et al, 2007). Jumlah replikasi berdasarkan jumlah konsentrasi perlakuan adalah 4 ulangan.

\section{Variabel Penelitian}

Variabel bebas penelitian adalah konsentrasi ekstrak Curcuma xanthorrhiza Roxb. dengan konsentrasi masing-masing 6,25 $\mu \mathrm{g} / \mathrm{ml}, 12,5 \mu \mathrm{g} / \mathrm{ml}, 25 \mu \mathrm{g} / \mathrm{ml}, 50 \mu \mathrm{g} / \mathrm{ml}$ dan $100 \mu \mathrm{g} / \mathrm{ml}$ (Anjusha, 2014). Variabel terikat pada penelitian ini adlaah aktivitas antibakteri yang diukur berdasarkan Kadar Hambat Minimum (KHM) dan Kadar Bunuh Minimun (KBM) pada media MHA serta perubahan struktur dinding sel bakteri $P$. acnes.

\section{Tempat Penelitian}

1. Ekstrak Curcuma xanthoriza diperoleh dari Javaplant PT. Tri Rahardja Surakarta.

2. Proses uji antibakteri ekstrak temulawak dilaksanakan di Laboratorium Instalasi Mikrobiologi Klinik RSUD Dr. Soetomo Surabaya

3. Proses pengeringan sampel MES dilaksanakan di UPT. Mikroskop Elektron, Fakultas Kedokteran Universitas Airlangga, Surabaya dan di Laboratorium I eknık Mesın Instıtut I leknologı sepulun November Surabaya.

4. Penelitian dilaksanakan pada bulan Januari 2019

\section{Prosedur Penelitian}

Pembuatan Media Mueller Hinton Agar dilakukan dengan menimbang 9,5 gram MHA, masukkan dalam gelas baker berisi aquadest sebanyak $250 \mathrm{~mL}$. MHA dihomogenkan dengan magnetic stirer dan dipanaskan pada hot plate selama \pm 20 menit pada sushu $150^{\circ} \mathrm{C}$. Media harus benar-benar homogen yang terlihat dari warna kuning bening. Masukkan MHA pada tabung erlenmeyer 500 $\mathrm{ml}$, tutup dengan kapas dan lakukan sterilisasi pada autoklaf selama 15 menit pada suhu $121^{\circ} \mathrm{C}$ dan tekanan 1,5 atm. Selanjutnya menyiapkan 6 erlenmeyer kemudian berikan label sesuai dengan perlakuan P1, P2, P3, P4 P5 dan K (kontrol).

Prosedur pembuatan media MHA yang mengandung ekstrak etanol Curcuma xanthorrhiza Roxb. berbagai konsentrasi adalah:

a. Konsentrasi larutan stok yang digunakan adalah $\quad 1.000 \quad \mu \mathrm{g} / \mathrm{mL} \quad$ kemudian ditambahkan MHB dengan seri konsentrasi pengenceran yang digunakan adalah $100 \%$, $50 \%, 25 \%, 12,5 \%, 6,25 \%$ dan $0 \%$.

b. Larutan diinkubasi pada suhu $25^{\circ} \mathrm{C}$ selama 24 jam.

c. Larutan dari setiap erlenmeyer kemudian dituangkan ke MHA pada dalam cawan petri masing-masing berisi $10 \mathrm{~mL}$.

d. Ditunggu sampai media di dalam plate memadat.

e. Media yang sudah dilakukan inokulasi bakteri P.acnes sebanyak $1,5 \times 10^{4} \mathrm{CFU}$ ke setiap permukaan media MHA di cawan petri dengan metode mayo.

f. Media uji diinkubasi pada suhu $35^{\circ} \mathrm{C}$ selama 24 jam sebelum dilakukan pengamatan

Pengamatan menggunakan MES untuk mengetahui sifat aktivitas antimikroba ekstrak etanol Curcuma xanthorrizha terhadap $P$. acnes dan mengetahui adanya perubahan pada struktur dinding sel $P$. acnes dengan mengamati ukuran (diameter) sel bakteri $P$. acnes, keadaan dinding sel bakteri $P$. acnes dan jumlah sel bakteri $P$. acnes perlapangan pandang. Pengujian SEM dilakukan terhadap 
media uji MHA dan koloni $P$. acnes dari konsentrasi $0 \mu \mathrm{g} / \mathrm{mL}$ (Kontrol) serta MHA dengan ekstrak Curcuma xanthorriza konsentrasi $25 \mu \mathrm{g} / \mathrm{mL}$ (P3).

Efek antibakteri ekstrak etanol Curcuma xanthorrhiza Roxb. terhadap Propionibacterium acnes secara in vitro ditentukan dari ada atau tidak adanya bakteri P.acnes pada media MHA yang mengandung ekstrak etanol Curcuma xanthorrhiza Roxb. pada berbagai konsentrasi. Gambaran perubahan struktur dinding sel P.acnes diamati pada Microscope Electrone Screening (MES). Hasil pemeriksaan MES dijabarkan secara deskriptif.

\section{HASIL DAN PEMBAHASAN}

Penentuan nilai KHM dilakukan dengan mengidentifikasi konsentrasi ekstrak terendah yang telah mampu menghambat pertumbuhan bakteri, ditandai dengan P.acnes tumbuh minimal dibandingkan dengan konsentrasi kontrol. Hasil pengujian KHM ekstrak Curcuma xanthorrhiza Roxb. terhadap pertumbuhan bakteri P.acnes dapat dilihat pada tabel berikut:

Tabel 1. Hasil Pengamatan Kadar Hambat Minimum (KHM) Ekstrak Etanol Curcuma xanthorrhiza Roxb. Terhadap Bakteri P.acnes

\begin{tabular}{|c|c|c|c|c|c|}
\hline & & Konser & rasiEks & rak & \\
\hline $\mathrm{R}$ & $\begin{array}{c}100 \\
\mu \mathrm{g} / \mathrm{ml}\end{array}$ & $\begin{array}{cc}50 & 25 \\
\mu \mathrm{g} / \mathrm{ml} & \mu \mathrm{g} / \mathrm{ml}\end{array}$ & $\begin{array}{r}12,5 \\
\mu \mathrm{g} / \mathrm{ml}\end{array}$ & $\begin{array}{c}6,25 \\
\mu \mathrm{g} / \mathrm{ml}\end{array}$ & $\begin{array}{c}\text { Kontrol } \\
(0 \mu \mathrm{g} / \mathrm{ml})\end{array}$ \\
\hline R1 & - & + & ++ & ++ & ++ \\
\hline R2 & - & + & ++ & ++ & ++ \\
\hline R3 & - & + & ++ & ++ & ++ \\
\hline $\mathrm{R} 4$ & - & + & ++ & ++ & ++ \\
\hline $\begin{array}{l}\text { Kete } \\
\text { Neg. }\end{array}$ & $\begin{array}{l}\text { ggan: } \\
(-)\end{array}$ & $\begin{array}{l}\text { : Tidak ad } \\
\text { P.acnes pa }\end{array}$ & $\begin{array}{l}\text { pertu } \\
\text { medi }\end{array}$ & $\begin{array}{l}\text { nbuhan } \\
\text { MHA }\end{array}$ & bakteri \\
\hline Posi & if $(+)$ & $\begin{array}{l}\text { : Ada pertu } \\
\text { pada medi }\end{array}$ & $\begin{array}{l}\text { nbuhan } \\
\text { MHA }\end{array}$ & bakteri & P.acnes \\
\hline Posi & if $(++)$ & $\begin{array}{l}\text { Ada pertu } \\
\text { pada medi } \\
\text { tinggi }\end{array}$ & $\begin{array}{l}\text { mbuhan } \\
\text { MHA }\end{array}$ & $\begin{array}{l}\text { bakteri } \\
\text { dengan }\end{array}$ & $\begin{array}{l}\text { i P.acnes } \\
\text { kuantitas }\end{array}$ \\
\hline
\end{tabular}

Berdasarkan hasil pada 5.1 diatas diperoleh hasil bahwa ekstrak Curcuma xanthorrhiza Roxb. memiliki daya antibakteri terhadap bakteri P.acnes pada MHA dengan konsentrasi ekstrak $25 \mu \mathrm{g} / \mathrm{ml}, 12,5 \mu \mathrm{g} / \mathrm{ml}$ dan
$6,25 \mu \mathrm{g} / \mathrm{ml}$ yang ditunjukkan dengan adanya pertumbuhan bakteri pada MHA yang diinokulasi P.acnes demikian pula pada MHA dan MHB pada konsentrasi kontrol juga terdapat pertumbuhan bakteri P.acnes dalam jumlah yang cukup banyak. Berdsarkan hasil pengamatan tampak bahwa konsentrasi terendah yang mampu menghambat pertumbuhan bakteri yang ditunjukkan dengan sedikitnya bakteri yang umbuh adalah pada konsentrasi $25 \mu \mathrm{g} / \mathrm{ml}$, oleh karena itu dapat disimpulkan bahwa ekstrak Curcuma xanthorrhiza Roxb. memiliki nilai KHM terhadap bakteri P.acnes pada konsentrasi 25 $\mu \mathrm{g} / \mathrm{ml}$.

Kadar Bunuh Minimum (KBM) dinilai dengan mengam ati konsentrasi terendah yang menunjukkan tidak adanya pertumbuhan bakteri pada media Mueller Hinton Agar (MHA) pada cawan petri yang sudah diinokulasikan sediaan uji. Konsentrasi terkecil yang dapat membunuh bakteri, ditandai dengan P.acnes sudah tidak dapat tumbuh pada hasil goresan di cawan menandakan bakteri uji mati karena larutan uji dengan konsentrasi tersebut.

Tabel 2. Hasil Pengamatan Kadar Bunuh Minimum (KBM) Ekstrak Etanol Curcuma xanthorrhiza Roxb. Terhadap Bakteri P.acnes

\begin{tabular}{|c|c|c|c|c|c|c|}
\hline \multirow[b]{2}{*}{$\mathrm{R}$} & \multicolumn{6}{|c|}{ KonsentrasiEkstrak } \\
\hline & $\begin{array}{c}100 \\
\mu \mathrm{g} / \mathrm{ml}\end{array}$ & $\begin{array}{c}50 \\
\mu \mathrm{g} / \mathrm{ml}\end{array}$ & $\begin{array}{c}25 \\
\mu \mathrm{g} / \mathrm{ml}\end{array}$ & $\begin{array}{c}12,5 \\
\mu \mathrm{g} / \mathrm{ml}\end{array}$ & $\begin{array}{c}6,25 \\
\mu \mathrm{g} / \mathrm{ml}\end{array}$ & $\begin{array}{c}\text { Kontrol } \\
(0 \mu \mathrm{g} / \mathrm{ml}) \\
\end{array}$ \\
\hline R1 & - & - & + & ++ & ++ & ++ \\
\hline $\mathrm{R} 2$ & - & - & + & ++ & ++ & ++ \\
\hline R3 & - & - & + & ++ & ++ & ++ \\
\hline $\mathrm{R} 4$ & - & - & + & ++ & ++ & ++ \\
\hline
\end{tabular}

Keterangan:

Negatif (-) : Tidak ada pertumbuhan bakteri P.acnes pada media MHA

Positif (+) : Ada pertumbuhan bakteri P.acnes pada media MHA

Positif (++) : Ada pertumbuhan bakteri P.acnes pada media MHA dengan kuantitas tinggi

Berdasarkan tabel 5.2 dapat dilihat pada replikasi R1-R4 pada media MHA yang berisi konsentrasi ekstrak $50 \mu \mathrm{g} / \mathrm{ml}$ dan $100 \mu \mathrm{g} / \mathrm{ml}$ tidak tampak adanya pertumbuhan P.acnes. Sedangkan pada MHA yang mengandung ekstrak Curcuma xanthorrhiza Roxb. dengan konsentrasi $25 \mu \mathrm{g} / \mathrm{ml}-6,25 \mu \mathrm{g} / \mathrm{ml}$ serta pada 
MHA kontrol bakteri P.acnes tampak tumbuh pada media. Hasil pengamatan diatas tampak bahwa konsentrasi terendah yang mampu menghasilkan MHA yang tidak ditumbuhi bakteri P.acnes adalah konsentrasi $50 \mu \mathrm{g} / \mathrm{ml}$, maka dapat disimpulkan bahwa nilai Kadar Bunuh Minimum (KBM) P.acnes pada perlakuan ekstrak Curcuma xanthorrhiza Roxb. adalah $50 \mu \mathrm{g} / \mathrm{ml}$. Berikut hasil pengamatan pertumbuhan bakteri P.acnes perlakuan ekstrak Curcuma xanthorrhiza konsentrasi $50 \mu \mathrm{g} / \mathrm{ml}$ pada 4 replikasi yang dilakukan baik pada media MHA maupun MHB. Hasil pengujian aktivitas antibakteri dengan metode dilusi agar menunjukkan aktivitas antibakteri terhadap bakteri $P$. acnes dengan nilai KHM $25 \mu \mathrm{g} / \mathrm{ml}$ dan KBM 50 $\mu \mathrm{g} / \mathrm{ml}$. Koloni bakteri $P$. acnes yang diperoleh dari uji antibakteri menggunakan metode dilusi agar pada konsentrasi ekstrak Curcuma xanthorrhiza Roxb. 0\% (K) dan 25\% dilanjutkan dengan pemeriksaan menggunakan Scanning Electron Microscopy pada pembesaran $5.000-20.000$ kali untuk mengetahui gambaran perubahan struktur dinding sel bakteri $P$. acnes.

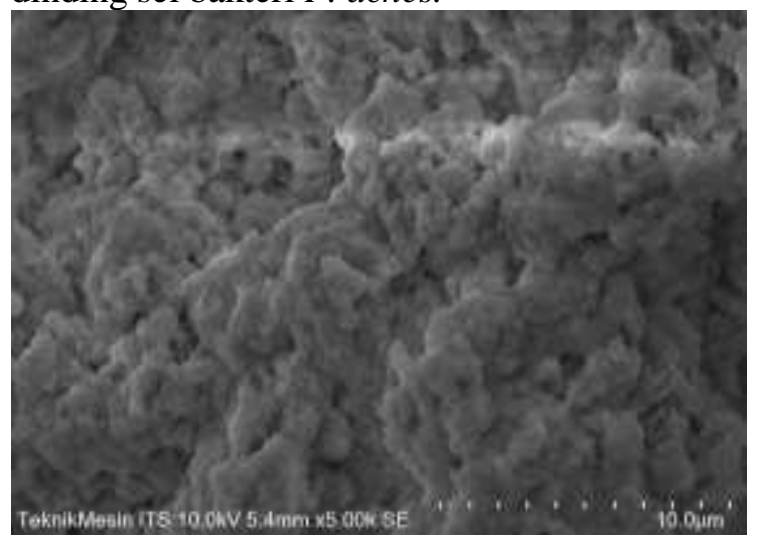

Gambar 2 Hasil Mikrograf Scanning Electron Microscopy (SEM) Bakter1 P. acnes yang Tidak Dipapar Dengan Ekstrak Etanol Curcuma xanthorrhiza Roxb. Pada Pembesaran 5.000 Kali

Berdasarkan hasil pengamatan diatas terlihat, bahwa bakteri P.acnes pada kelompok kontrol terlihat padat dengan kondisi dinding sel bakteri utuh.

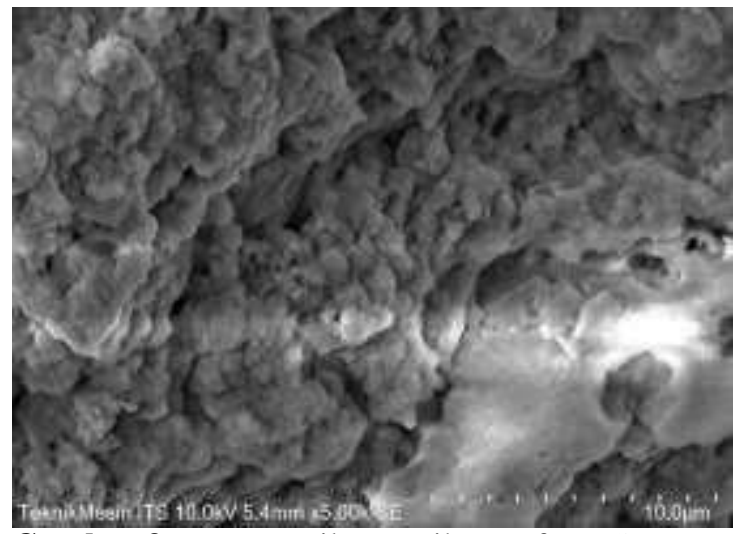

Gambar 3. Hasil Mikrograf Scanning Electron Microscopy (SEM) Bakteri P. acnes yang Terpapar Ekstrak Etanol Curcuma xanthorrhiza Roxb. dengan Konsentrasi 25\% Pada Pembesaran 5.000 Kali

Hasil pengamatan dinding sel bakteri P.acnes yang terpapar ekstrak etanol Curcuma xanthorrhiza Roxb. dengan konsentrasi 25\% terjadi perubahan morfologi berupa dinding sel yang kasar akibat penyusutan serta adanya dinding sel yang hancur sehingga sitoplasma keluar dan tampak seperti meleleh

\section{Analisis Hasil Penelitian}

\section{Efek Antibakteri Ekstrak Etanol Curcuma xanthorrhiza Roxb}

Hasil uji antibakteri ekstrak etanol Curcuma xanthorrhiza Roxb. terhadap P.acnes secara in vitro dengan metode dilusi agar diketahui nilai $\mathrm{KHM}$ adalah $25 \mu \mathrm{g} / \mathrm{ml}$, karena pada konsentrasi tersebut media uji tampak jernih yang menunjukkan tidak adanya pertumbuhan bakteri. Nilai dari kadar hambat minimal ini dapat ditentukkan dari tingkat kekeruhan dari setiap media, kekeruhan tersebut diakibatkan adanya pertumbuhan bakteri pada media uji.

Konsentrasi minimal ekstrak Curcuma xanthorrhiza Roxb. yang mampu membunuh P.acnes dinilai dengan mengamati adanya pertumbuhan bakteri pada media MHA yang telah digoreskan sediaan uji masing-masing konsentrasi. Hasil pengamatan setelah dilakukan inkubasi selama 24 jam pada suhu $35^{\circ} \mathrm{C}$, bakteri P.acnes tidak dapat tumbuh pada konsentrasi ekstrak $100 \mu \mathrm{g} / \mathrm{ml}$ dan $50 \mu \mathrm{g} / \mathrm{ml}$. Sehingga dari hasil penelitian ini, konsentrasi $50 \mu \mathrm{g} / \mathrm{ml}$ ditetapkan sebagai nilai KBM dari 
ekstrak etanol Curcuma xanthorrhiza Roxb. yang mampu membunuh bakteri P.acnes.

\section{Gambaran Perubahan Struktur Dinding Sel Bakteri P.acnes}

Hasil pemeriksaan menggunakan SEM terhadap bakteri P.acnes yang tidak dipapar dengan ekstrak etanol Curcuma xanthorrhiza Roxb. $0 \mu \mathrm{g} / \mathrm{ml}$. (K) menunjukkan sel bakteri P.acnes tidak mengalami kerusakan morfologi dinding sel. Pertumbuhan bakteri P.acnes terlihat rapat dengan kondisi dinding sel bakteri utuh (Gambar 5.2). Sedangkan hasil pemeriksaan menggunakan SEM terhadap bakteri P.acnes yang dipapar dengan ekstrak etanol Curcuma xanthorrhiza Roxb. konsentrasi $25 \mu \mathrm{g} / \mathrm{ml} \quad$ (P3), menunjukkan sel bakteri P.acnes mengalami perubahan morfologi berupa timbulnya dinding sel kasar kasar akibat penyusutan serta adanya dinding sel yang hancur sehingga sitoplasma keluar dan tampak seperti meleleh.

\section{PEMBAHASAN}

Hasil penelitian didapatkan bahwa terdapat hubungan antara pemberian konsentrasi bertingkat ekstrak etanol Curcuma xanthorrhiza Roxb. terhadap hambatan pertumbuhan P.acnes, dimana semakin tinggi konsentrasi ekstrak maka semakin besar hambatan pertumbuhan sehingga makin sedikit jumlah bakteri P.acnes yang tumbuh. Kadar hambat minimal adalah konsentrasi terendah yang menunjukan pertumbuhan bakteri dalam jumlah minimal dibandingkan dengan konsentrasi kontrol, adapun nilai KHM pada penelitian ini adlaah $25 \mu \mathrm{g} / \mathrm{ml}$. Kadar bunuh minimal adalah konsentrasi terendah yang dapat membunuh pertumbuhan bakteri dan diamati berdasarkan tidak adanya pertumbuhan bakteri pada media agar. Pengamatan hasil uji dilusi agar menunjukkan bahwa konsentrasi $50 \mu \mathrm{g} / \mathrm{ml}$ merupakan KBM yang ditandai dengan tidak ditemukan pertumbuhan bakteri P.acnes pada media agar.

Hasil penelitian ini menunjukan bahwa ekstrak Curcuma xanthorrhiza Roxb. memiliki daya antibakteri terhadap pertumbuhan
P.acnes yang merupakan jenis bakteri gram positif. Hasil ini sesuai dengan penelitian yang dilakukan oleh Diastuti (2014) yang menunjukan ekstrak Curcuma xanthorrhiza Roxb. yang mengandung $\alpha$-curcumene, xanthorrizol dan monoterpen memiliki efek antibakteri yang signifikan terhadap bakteri gram positif Bacillus subtilis dan Staphylococcus aureus serta bakteri gram negatif Pseudomonas aeruginosa dengan nilai KBM sebesar 15,6 $\mu \mathrm{g} / \mathrm{mL}$ baik pada ekstrak dengan ekstraksi aceton maupun $n$ hexane. Efek antibakteri Curcuma xanthorrhiza Roxb. lemah terhadap bakteri gram negatif Shigella dysenteriae dan Vibrio cholerae, serta tidak memiliki efek antibakteri terhadap bakteri gram negatif Escherichia coli, Enterobacter aerogenes dan Salmonella thypi.

Hasil penelitian Diastuti (2014) memiliki nilai KBM yang lebih rendah daripada penelitian ini. Hal ni dikarenakan perbedaan cara hidup bakteri. P.acnes merupakan bakteri anaerob aerotoleran yang berarti bakteri ini dapat hidup walaupun tidak terdapat oksigen disekitamya, sedangkan $B$. subtilis bersifat strict aerob dan $S$. aureus serta $P$. aeruginosa bersifat aerobik atau mikroaerofilik yang berarti bakteri ini masih bisa bertahan dalam kadar oksigen yang rendah, namun tidak dapat bertahan ketika tidak ada oksigen (Cobas, 2010). Sehingga diperlukan konsentrasi yang lebih agar mampu membunuh P.acnes pada penelitian ini.

Penelitian lainnya oleh Adila (2013) menyebutkan bahwa ekstrak Temulawak memberikan daya hambat terhadap ketiga mikroba uji Candida albicans (13,07 mm), Staphylococcus aureus $(15,75 \mathrm{~mm})$ dan Eschericia coli $(31,56 \mathrm{~mm})$. KHM dan KBM ekstrak segar rimpang temulawak terhadap $E$. coli masing-masing $12,5 \%$ dan $25 \%$. Sedangkan pada $C$. albicans dan $S$. aureus ekstrak segar temulawak tidak mampu membunuh bakteri uji. Perbedaan nilai tersebut dapat disebabkan oleh struktur dinding sel E.coli yang berbeda dengan $S$. aureus dan $C$. albicans, dimana $E$. coli meskipun tergolong pada bakteri gram negatif yang memiliki susunan dinding sel rumit namun E.coli memiliki protein porin pada membran luar dinding sel yang berfungsi 
sebagai saluran keluar masuknya senyawa aktif, sehingga senyawa aktif pada temulawak akan mudah masuk dan merusak aktivitas enzim sel yang menyebabkan kerusakan sel $E$. coli (Sunatmo, 2009). Sedangkan pada $C$. albicans meskipun tergolong bakteri gram positif namun struktur selnya terjadi pembentukan klamidospora yang membentuk dinding lebih tebal sehingga sulit ditembus oleh senyawa antimikroba (Jawetz, et al., 2011)

Hasil penelitian oleh Adila (2013) tersebut mendukung hasil penelitian ini dimana ekstrak Curcuma xanthorriza Roxb. mampu untuk membunuh bakteri. Akan tetapi pada penelitian Adilla (2013) ekstrak segar rimpang temulawak tidak dapat membunuh $C$. albicans. P.acnes sebagai bakteri gram positif non spora dan tersusun dari polimer yang bersifat polar sehingga mudah ditembus oleh antibakteri (Dewi, 2010). Dibandingkan dengan $C$. albicans, meskipun sama-sama tergolong bakteri gram positif namun $C$. albicans, mampu membentuk spora yang dapat melindunginya dinding selnya dari pengaruh antibakteri.

Hasil pemeriksaan menggunakan SEM terhadap bakteri P.acnes yang dipapar dengan ekstrak etanol Curcuma xanthorrhiza Roxb. konsentrasi $25 \mu \mathrm{g} / \mathrm{ml} \quad$ (P3), menunjukkan sel bakteri P.acnes mengalami perubahan morfologi berupa timbulnya diding sel kasar akibat penyusutan serta adanya dinding sel yang hancur sehingga sitoplasma keluar dan tampak seperti meleleh. Hal ini selan disebabkan oleh kandungan xanthorrizol juga disebabkan oleh kandungan curcumin yang dmiliki Curcuma xanthorriza Roxb. Hasil penelitian lain oleh Tyagi (2015) melaporkan bahwa Curcumin memiliki antibakteri terhadap semua bakteri uji baik dari kelompok Gram positif maupun Gram negatif dan daya bunuh meningkat seiring peningkatan dosis dan waktu inkubasi. Daya bunuh curcumin $100 \%$ terhadap bakteri uji dengan dosis 100 $\mu \mathrm{M}$ curcumin bahkan ketika diujikan pada bakteri dengan kepadatan yang lebih tinggi (106 CFU/ml). Sedangkan ditinjau dari pengamatan dilaporkan bawah terjadi perubahan kekasaran permukaan dan timbulnya lekuk pada dinding sel. Pada inkubasi dengan dosis yang lebih tinggi menyebabkan terjadinya kebocoran dinding sel.

Dinding sel bakteri berfungsi melindungi membran sitoplasma, memelihara bentuk sel, dan mencegah lisis karena tekanan osmosis. Jika dinding sel rusak atau tidak terbentuk sel akan lisis atau tidak dapat membelah. Lisisnya sel terjadi karena cairan disekitar yang hipoosmosis berdifusi ke dalam sel menyebabkan pembengkakan (swell) dan diikuti lisis (Priyanto, 2010).

Sebagian besar akne ringan sampai sedang membutuhkan terapi topikal. Acne sedang sampai berat menggunakan kombinasi terapi topikal dan oral. Terapi acne dimulai dari pembersihan wajah menggunakan sabun. Beberapa sabun sudah mengandung antibakteri, misalnya triclosan yang menghambat kokus positif gram. Selainitu juga banyak sabun mengandung benzoil peroksida atau asam salisilat (Yenni, dkk, 2011). Secara in vitro, P.acnes sangat sensitif terhadap beberapa antibiotik dari golongan yang berbeda, termasuk makrolida, tetrasiklin, penisilin, klindamisin, sefalosporin, trimetoprin, dan sulfonamid. Azitromisin merupakan antibakterial yang mengandung nitrogen dan merupakan derivat metal dari eritromisin dengan mekanisme kerja dan penggunaan yang mirip dengan eritromisin (Ramdani, 2015).

Kandungan minyak atsiri yang diduga bekerja pada bakteri adalah terpenoid, phenol. Terpenoid merupakan metabolit sekunder yang memberikan bau-bauan pada tumbuhan dan diduga memiliki kemampuan secara aktif melawan bakteri, jamur, dan protozoa. Terpenoid yang disebut dengan petalostemumol memperlihatkan aktifitas terhadap Bacillus subtilis, dan Candida albicans (Naim, 2004). Terpenoid aktif melawan bakteri, tetapi mekanisme antibakterial terpenoid masih belum benarbenar diketahui. Aktifitas antibakteri terpenoid diduga melibatkan pemecahan membran oleh komponen-komponen lipofilik (Cowan, 1999).

Ekstrak Curcuma xanthorriza Roxb. memiliki senyawa antimikroba yang khas yaitu xanthorrizol yang tidak dimiliki oleh rimpang Curcuma yang lain meskipun 
kandungan tersebut hanya dalam jumlah sangat kecil. Hal ini sesuai dengan pernyataan Hansel (1980) yaitu senyawa xhantorrizol pada temulawak $\geq 6 \%$ sedangkan pada kunyit $\geq 3 \%$. Senyawa xanthorrizol merupakan senyawa aktif antibakteri utama yang terdapat dalam rimpang temulawak Aktivitas antibakteri dari xanthorrizol mempunyai stabilitas yang baik terhadap panas, yakni pada temperatur tinggi antara $60-121^{\circ} \mathrm{C}$. Hasil penelitian Fatmawati (2008) juga mendapati bahwa bahwa kandungan xanthorrizol mampu menghambat pertumbuhan Streptococcus mutans dan $S$. aureus.

Respon daya hambat pertumbuhan bakteri yang dihasilkan Curcuma xanthorrhiza Roxb. dipengaruhi oleh senyawa aktif yang terkandung didalamnya seperti minyak atsiri, alkaloid, flavonoid, tanin, kurkuminoid dan terpenoid (Rukmana, 2014). Senyawa flavonoid mampu merusak dinding sel sehingga menyebabkan kematian sel. Flavonoid juga dapat menghambat pembentukan protein sehingga menghambat pertumbuhan bakteri. Selain flavonoid kandungan senyawa lain seperti senyawa tanin juga dapat merusak membran sel. Senyawa tanin dapat merusak pembentukan konidia jamur. Kandungan senyawa lain seperti alkaloid dalam rimpang Curcuma xanthorriza Roxb. mampu mendenaturasi protein sehingga merusak aktivitas enzim dan menyebabkan kematian sel (Dermawaty, 2015).

Cikrici et al., (2008) menambahkan bahwa aktivitas antibakteri curcuminoid terhadap aktivitas bakteri dengan cara menghambat aktivitas enzim siklooksigenase-2 (cox-2) yang mengubah asam arakhidonat menjadi prostaglandin yang menyebabkan timbulnya rasa sakit.Curcuminoid merupakan senyawa fenolik yang juga dapat menghambat pertumbuhan bakteri dengan cara mendenaturasi dan merusak membran sel sehingga proses metabolisme sel akan terganggu.

\section{KESIMPULAN DAN SARAN}

Pemberian ekstrak Curcuma xanthorrhiza Roxb. memiliki efek antibakteri terhadap bakteri P.acnes secara in vitro yang diduga karena adanya kandungan senyawa xanthorrizol, alkaloid, flavonoid, tanin, kurkuminoid dan terpenoid. Konsentrasi ekstrak $25 \mu \mathrm{g} / \mathrm{ml}$ merupakan kadar minimum yang mampu menghambat (KHM) pertumbuhan P.acnes melalui dilusi cair, sedangkan konsentrasi minimal yang mampu membunuh (KBM) P.acnes adalah $50 \mu \mathrm{g} / \mathrm{ml}$. Bakteri P.acnes yang dipapar dengan ekstrak etanol Curcuma xanthorrhiza Roxb. mengalami perubahan morfologi berupa timbulnya dinding sel kasar kasar akibat penyusutan serta adanya dinding sel yang hancur sehingga sitoplasma keluar dan tampak seperti meleleh

\section{REFERENSI}

Afriyanti \& Rizqun, N., 2015. Akne Vulgaris Pada Remaja. Jurnal Majority Vol.4/No.6/ Februari 2015. Fakultas Kedokteran. Universitas Lampung.

Balouiri, Mounyr, et al. 2016. Methods for in vitro evaluating antimicrobial activity: A review. Journal of Pharmaceutical Analysis Vol. 6.

Clatici, Victor Gabriel, et al. 2015. Propionibacterium Acnes And Antibiotic Resistance - Impact On Public Health. Romanian Journal of Clinical and Experimental Dermatology - RoJCED. Online ISSN 2392-8697. 2. 242-247.

Coban, M., et al. 2017. Quality of Life in Patients with Mild or Moderate Akne vulgaris. Clinical Dermatology Open Access Journal. Vol. 2(5): 1

Jawetz, M. \& Adelberg's. 2011. Mikrobiologi Kedokteran, Edisi 23, diterjemahkan oleh Mudihargi, E.,dkk. Jakarta: ECG.

Kumala, Shirly., \& Pratiwi, A. A. (2014). Efek Antimikroba dari Kapang Endofit Ranting Tanaman Biduri. JFIOnline| Print ISSN 1412-1107| e-ISSN 2355696X, 7(2).

Leyden, J. J., et al. 2009. Clinical Considerations in the Treatment of Akne vulgaris and Other Inflammatory Skin Disorders: a Status Report. 
Jurnal Biosains Pascasarjana Vol. 20 (2018) pp

(C) (2018) Sekolah Pascasarjana Universitas Airlangga, Indonesia

Dermatologic Clinics Journal, 27(1), 115. doi:10.1016/j.det.2008.07.008

Madelina, W dan Sulistyaningsih. 2019. Review: Resistensi Antibiotik Pada Terapi Pengobatan Jerawat. Jurnal Farmaka Volume 16 Nomor 2

Niyomkam, P. et al. 2010, Antibacterial activity of Thai herbal extracts on acne involved microorganism, Jurnal, Pharm. Biol., 48(4), 375-380.

Sari, P.Y. 2010. Pengaruh Penggunaan Masker Biji Kembang Pukul Empat (Mirabilis jalapa L.) Terhadap Pengurangan Jerawat (Akne vulgaris) Tipe Ringan. Jurnal JTR UNJ Vol 8 No 8 (2015):

Science Direct. 2016. Transcriptomic analysis of Propionibacterium acnes biofilms in vitro. https://www.sciencedirect.com/scien ce/article/pii/ S1075996416301202 [Diakses tanggal 13 Agustus 2019]

Vilar GN, Filho JFS, Santos LA. 2015. Quality of Life, Self-esteem and psychosocial factors in Adolescents with Akne vulgaris. An Bras Dermatol. 90(5): 622-629.

Widaty, S, dkk. 2017. Panduan Praktik Klinis bagi Dokter Spesialis Kulit dan Kelamin di Indonesia. Jakarta: Perhimpunan Dokter Spesialis Kulit dan Kelamin.

Wijayakusuma, M. Hembing. 2007. Penyembuhan dengan Temulawak. Jakarta: Sarana Pustaka Prima

Yenni, Amin Safrudin, Djawad Khairuddin. 2011. Perbandingan Efektivitas Adapelene 0.1\% Gel Dan Isotretinoin $0.05 \%$ Gel Yang Dinilai Dengan Gambaran Klinis Serta ProfilInterleukin 1 (IL-1) Pada Akne vulgaris. JST Kesehatan.

Zaghi, F. 2011. Transmission And Scanning Electron Microscope Study Of Antimicrobial Effect Of Pholiphenol Compound. Am. Soc. Microbiol: 1-14 